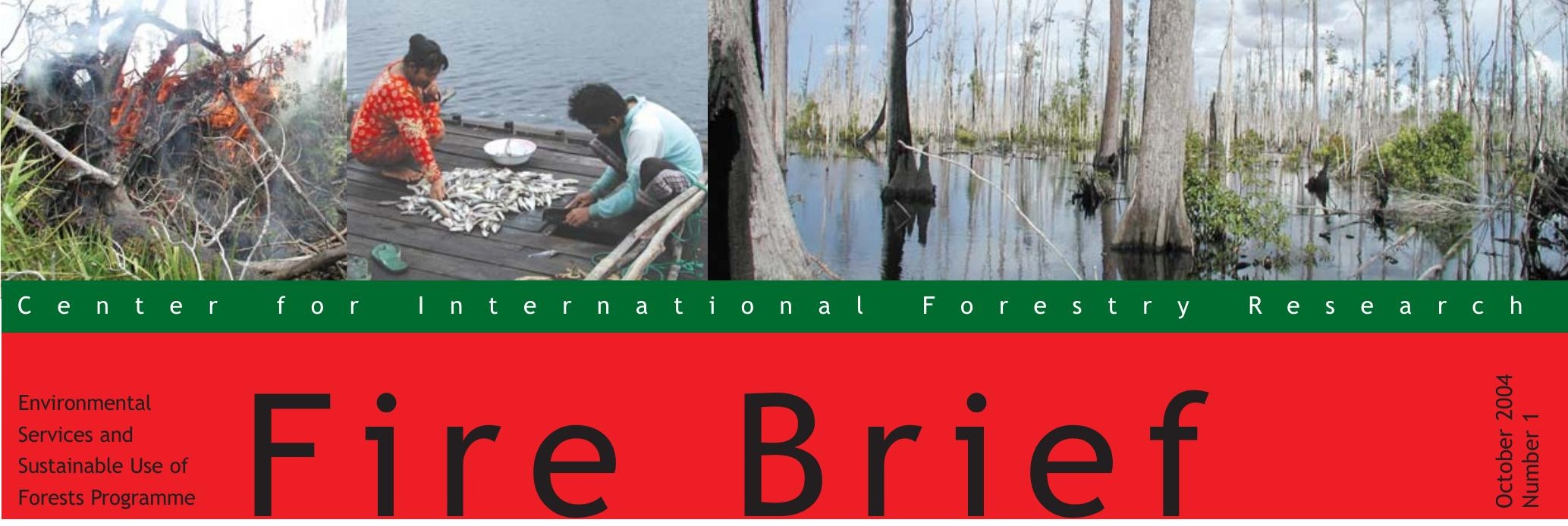

\title{
Fires in the Middle Mahakam peatlands: Balancing livelihoods and conservation
}

By Unna Chokkalingam (u.chokkalingam@cgiar.org), CIFOR

Large-scale, recurrent fires have dramatically affected Indonesia's peatlands in recent decades. Burning of peat and peat forests has had environmental impacts of concern on a regional and global scale, including high greenhouse gas emissions, acrid smoke and haze, and loss of critical carbon sinks and biodiversity. Major fires affected the Middle Mahakam peatlands in East Kalimantan during the drought years of 1982/83 and 1997/98, and minor fires have occurred on an annual basis. These fires arose from widespread community burning for livelihood activities in the peatlands.

\section{The Middle Mahakam peatlands}

The 500,000 ha basin includes the silty-clay banks of the Mahakam River and major tributaries, a series of shallow peat lakes, seasonally flooded plains and large forested peatlands beyond. Peat depth averages $8 \mathrm{~m}$ and is greater than $15 \mathrm{~m}$ in some areas. People living in the peatlands are pre-dominantly from the Kutai and Banjar ethnic groups. These groups use the proximate peatlands and lakes on an openaccess basis for harvesting fish, reptiles, sedges, timber and fuelwood. Fishing is the primary livelihood source. Villages are situated along the rivers and people enter the peatlands mainly through the rivers, canals, and lakes. There has been no large-scale commercial logging, land conversion or infrastructural development within the peatlands.

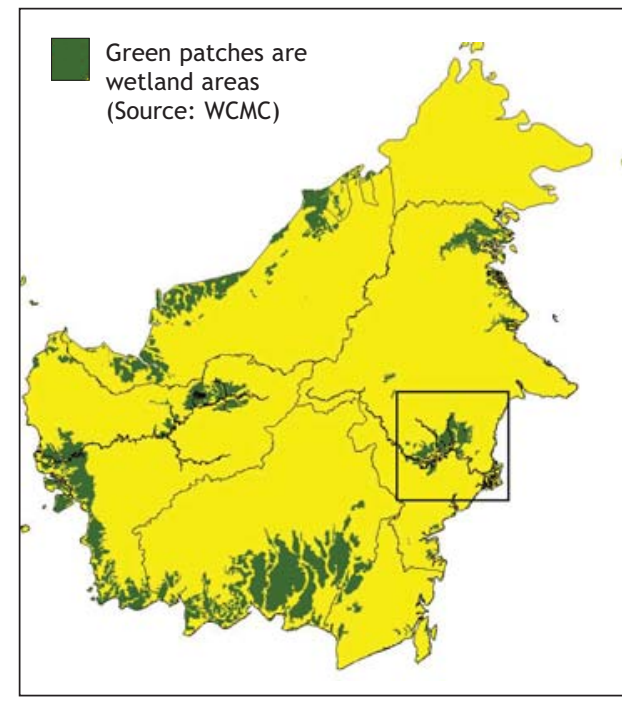

Location of the Middle Mahakam peatlands along the Mahakam river in East Kalimantan.

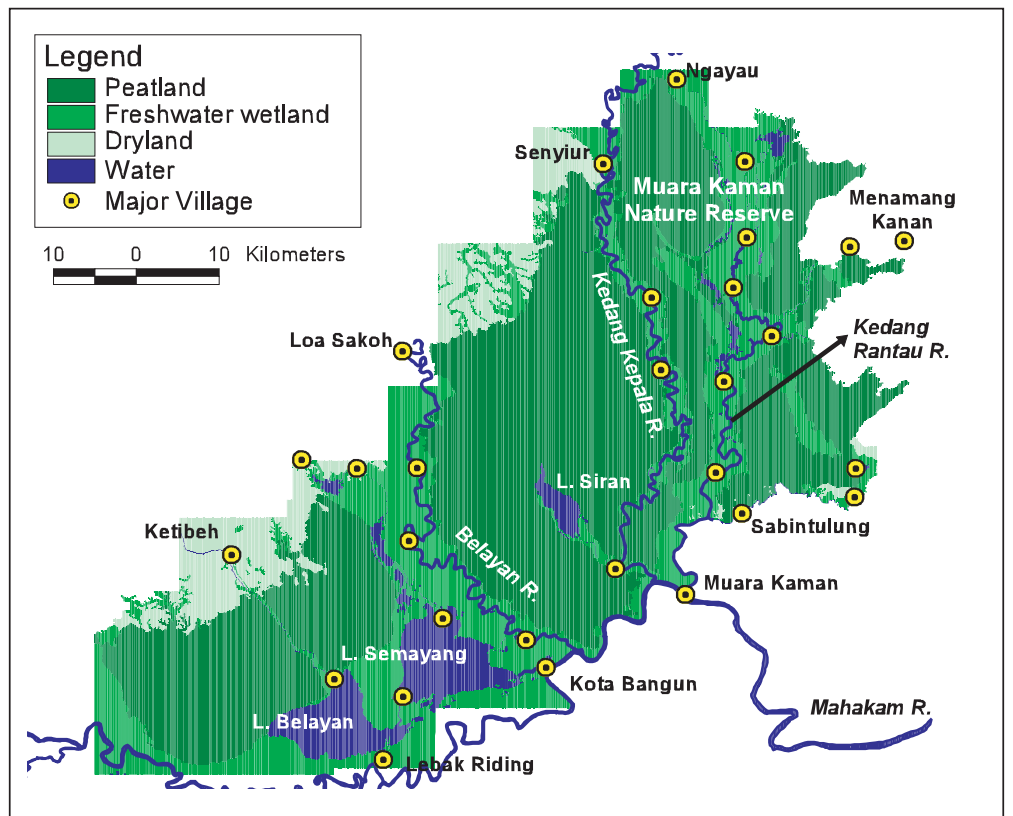

Key features of the Middle Mahakam study site. 


\section{Fire patterns and causes Annual fires}

Only $24 \%$ and $17 \%$ of the landscape were burnt in the non-El Niño periods of 1987-92 and 1992-97 respectively. Around $81 \%$ and $91 \%$ of these areas were burnt in previous periods, suggesting a high probability of repeated fires. Annual burning characteristic of this period was restricted primarily to accessible areas along the rivers, lakes and canals, as well as adjacent open-water sedge-grasslands or bare peat areas that were navigable by boat in the wet season. Local communities and migrants use fire here to clear vegetation and improve access to the peatlands for collecting fish and other resources, and to enhance fish habitat by creating and expanding open floodplains areas and pools in the degraded peat forests.

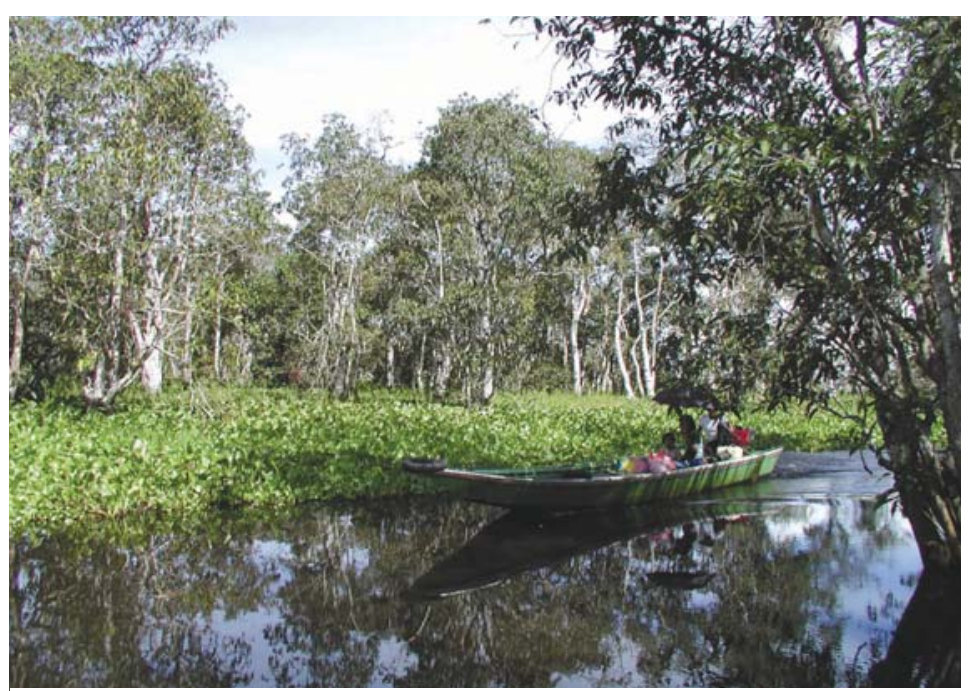

Annually burnt vegetation along a river. (Photo by Yayat Ruchiat)

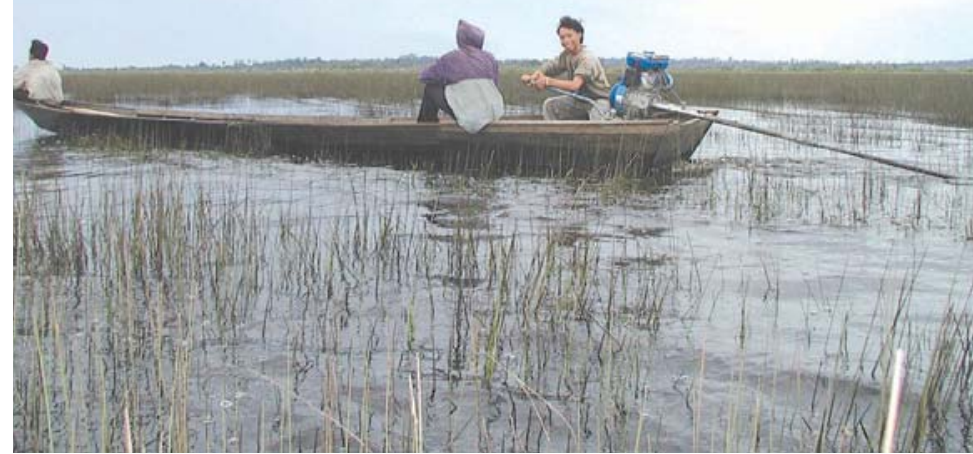

Annually burnt sedge floodplain navigable by boat. (Photo by Yayat Ruchiat)

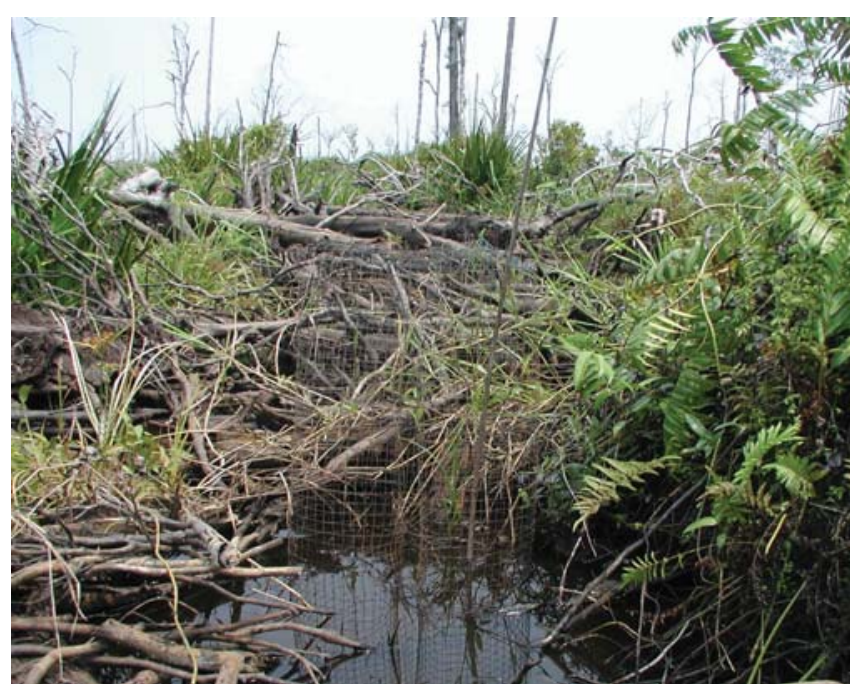

Pool of water containing fish in a burnt peat forest. (Photo by Andi Erman)

\section{2-83 El Niño fires}

Up to $45 \%$ of the study site may have been burnt in these fires. The fires spread from annual burn areas close to the waterways, inland into adjacent dry forests. The fires also possibly arose from increased human activity within the adjacent forests themselves during the long drought period.

\section{7-98 El Niño fires}

In this period, around $72-85 \%$ of the Middle Mahakam peatlands were burnt; $54 \%$ of it was mature forest that had not burnt before. These extensive fires are attributed to extremely dry conditions and burning by local communities and migrants in the course of turtle hunting and collecting tree bark. Fishing, the main livelihood source, was constrained by the drop in river levels, which made navigation and transport of fish difficult. New high-value markets emerged for turtle meat and for tree bark as an ingredient in commercial mosquito coils. The local government permitted quota-free collection of turtles in response to the drought crisis. Thousands of people switched to these alternative activities and entered remote interior peat forests that were scarcely visited before. Fire was used to improve access into the forest, for camping, and to concentrate the turtles in damp areas and catch them easily by burning off the surrounding vegetation. While these activities got local people through a difficult drought year as intended, they resulted in widespread fires that damaged the entire peat ecosystem and contributed to the smoke and haze problem. 


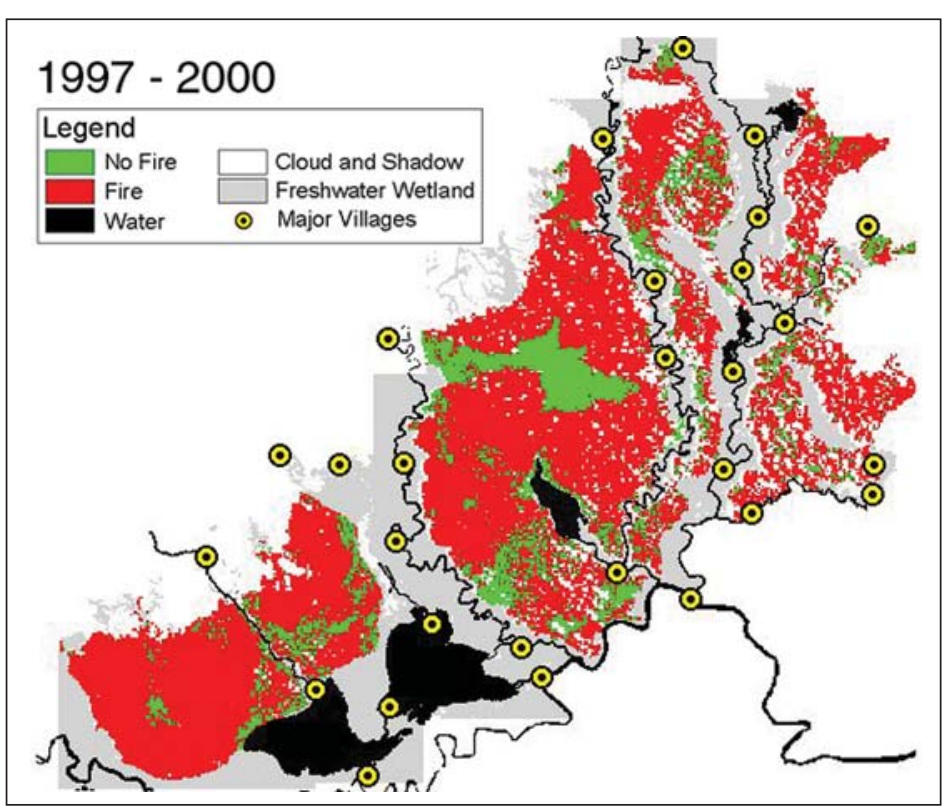

Peatland area affected by fire between 1997-2000 in the Middle Mahakam study site.

Impacts and recovery potential Closed-canopy forests decreased drastically in area from $63 \%$ to $4 \%$ of the landscape following the 1997-98 fires, and medium canopy forest cover declined from $8 \%$ to $5 \%$. At least $83 \%$ of the landscape is now in secondary successional vegetation types (open canopy forests, scrubby vegetation, and sedge-grasslands), compared to 33\% in 1987.

Once degraded, peatlands are very susceptible to repeated burning. Repeated annual burning has occurred in many newly opened up areas since 1997-98, transforming partially burnt peat forests into open floodplains with removal of tree cover and collapse and loss of peat. Local respondents suggest it is common for areas opened up in long drought periods to be subsequently burned repeatedly and transformed in this manner for fishing purposes. The existing floodplains and shallow lakes were formed in this way.

Slightly to moderately burnt interior peat forests (up to $19 \%$ of the study site) show good potential for rapid regrowth. Interior areas that were more severely burnt in $1997-98$ (up to $41 \%$ of the study site) can also recover well if left alone. Local people rarely visit these interior areas in typical years. However, these newly burnt interior forest areas are in a highly flammable condition now. They carry substantial fuel loads of dead trees and dense understorey and liana growth, while their open canopies promote rapid drying. Another quick drought-related fire in these areas will likely be more intensive and cause more severe, longlasting damage.

\section{Driving forces behind}

\section{widespread community fire use}

1. Fire is an invaluable tool for communities using resources in peatlands, and there are no effective alternatives to fire use or incentives to avoid it.

2. People using the peatlands value fish more than the peat forests, and so they are not alarmed when repeated burning degrades the forests.

3. Technology and infrastructure development such as nylon gillnets, small canals, motorized boats, and road links to markets have increased the importance of fishing - in turn leading to more use of fire.

4. Communities using the peatlands have neutral, if not positive, views on how fire affects hydrology, fishing and livelihoods. The longterm effects on hydrology and fisheries need more detailed investigation.

\section{Driving forces behind the 1997/98 drought-related fires}

1. Extremely dry conditions in both the vegetation and peat enabled fires to easily ignite and spread.

2. Low river levels and transport difficulties constrained regular livelihood options such as fishing. Alternative sustainable options were not apparent.

3. New, high-value markets emerged for turtle meat and for tree bark as an ingredient in commercial mosquito coils.

4. Local government permitted quota-free collection of turtles to ease the economic crisis brought on by the drought, without a sound understanding of the environmental consequences.

\section{Local needs versus regional/global concerns}

What is the scope for resolving peatland fire problems given the perceived local benefits of using fire and regional to global environmental concerns about widespread burning? Banning fires and policing the ban is not a viable option, due to the inaccessible and difficult terrain, the large numbers of people using fire, and the importance of fire for resource extraction in the peatlands. Conservation and wise use of the Middle Mahakam peatlands requires local values and needs to be harmonised with non-local interests. 


\section{Possible approach for balancing livelihoods and conservation}

It is probably not possible or even necessary to prevent annual burning for cultivation on the alluvial strips and for fishing in the peatlands adjacent to the waterways. However, the gradual expansion of annual fires and forest degradation into the adjacent interior areas through fire escapes or deliberate burning to improve fishing should be stopped. Much of the interior areas of the Middle Mahakam peatlands could be rehabilitated to forest if burning during long drought periods could be prevented. This means preventing thousands of people entering deep inside the forests in search of tree bark, turtles, or other such resources during severe droughts and other crises.

\section{Recommendations:}

1. Develop an El Niño response program for the Middle Mahakam peatlands aimed at reducing fire use by communities and providing alternative sustainable livelihood options at these critical times, preferably outside this vulnerable ecosystem. Raise awareness and set up local institutions and regulations to support and implement the measures.

2. Examine the technical and socio-economic feasibility of practising controlled burning in the accessible riverbanks and floodplains, particularly in long drought years, so that fires are contained.

3. Explore the possibility of transfer payments from primarily non-local interests for interior peat forest conservation through initiatives such as the UNFCCC, CBD, the Ramsar Convention and the APMI. The benefits must be commensurate and flow directly to the communities that stand to lose economically from changing their land use.

4. Investigate whether recurrent widespread burning and landscape transformation have negative impacts on fish, health or water quality. If so, these results could be used to drive local interest in reducing degrading fire use and conserving the interior peat forests.

5. Prohibit large-scale developments (transmigration, plantations, agriculture, commercial logging and infrastructure) that deforest or drain the peatlands, improve access into the interior areas and further increase the population pressures.

\section{Main references}

1. Chokkalingam, U., Kurniawan, I. and Ruchiat, Y. 2004. Manuscript. Fire, livelihoods and environmental degradation in the Middle Mahakam Peatlands. CIFOR, Bogor, Indonesia.

2. Chokkalingam, U., Kurniawan, I., Buitenzorgy, M., Anwar, S. and Hope, G. 2004. Manuscript. Impacts of recent fires on biodiversity in the Middle Mahakam Peatlands. CIFOR, Bogor, Indonesia.

3. Christensen, M. S., A. Mulu, and A. Akbar. 1986. Investigations into the fishery of the Middle Mahakam Area. German-Indonesian Technical Cooperation for Area Development, Samarinda, East Kalimantan, Indonesia.

4. Jepson, P., Momberg, F. and van Noord, H. 1998. Trade in reptiles from the Middle Mahakam Lake Area, East Kalimantan, Indonesia, with evidence of a causal link to the forest fires associated with the 1997/98 El Niño phenomena. Bio-Regional Management and Integrated Park Management Project Technical Memorandum 3. WWF Indonesia/ EPIQ/USAID.
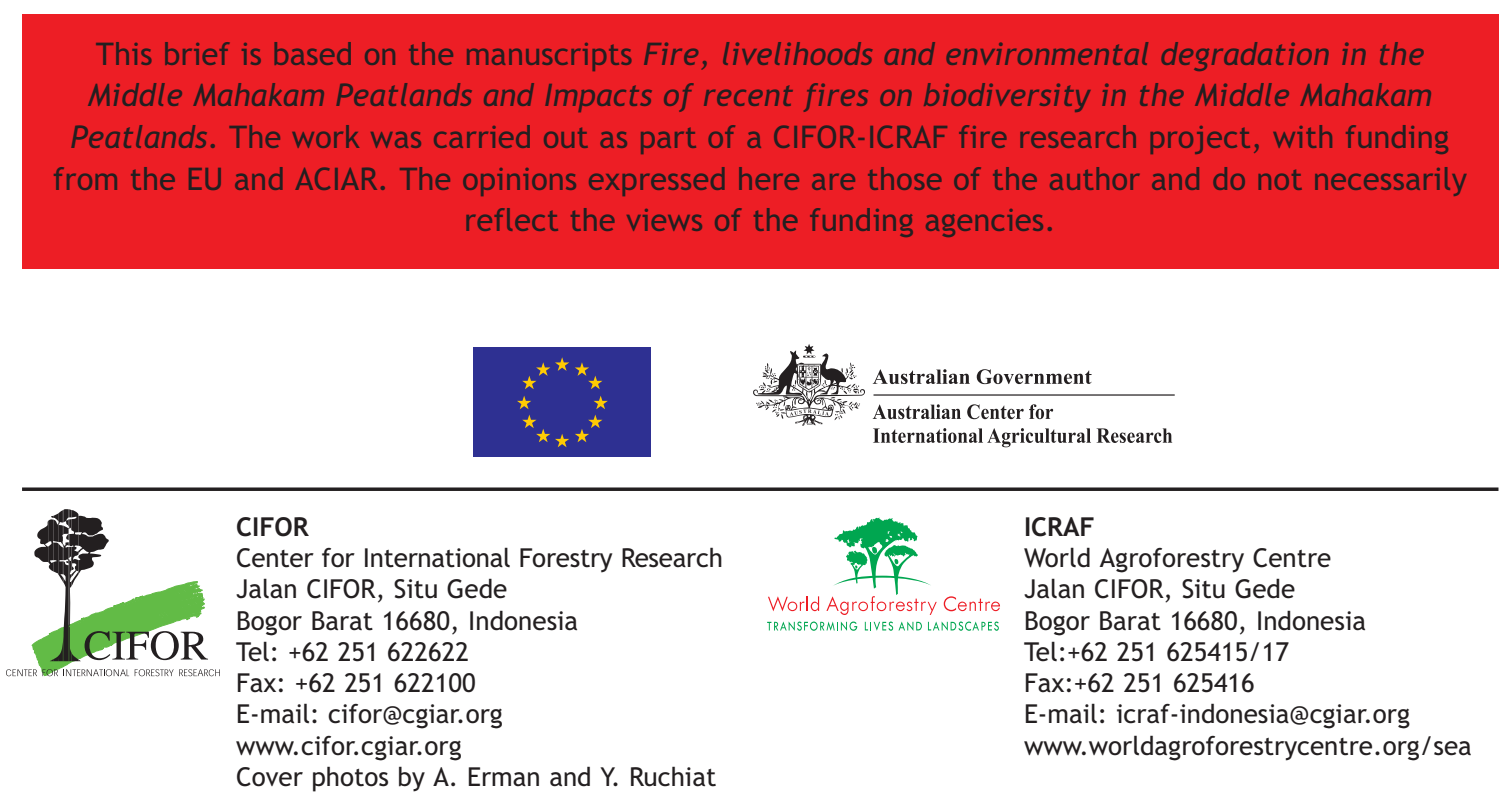

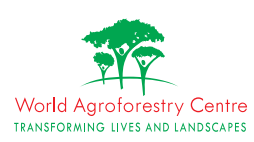

ICRAF

World Agroforestry Centre

Jalan CIFOR, Situ Gede

Bogor Barat 16680, Indonesia

Tel:+62 $251625415 / 17$

Fax:+62 251625416

E-mail: icraf-indonesia@cgiar.org

www.worldagroforestrycentre.org/sea

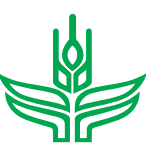

F U T URE HAR $/ /$ ES T 